\title{
CELL TYPE IN THE CHOICE OF CASES OF CARCINOMA OF THE BRONCHUS FOR SURGERY*
}

\author{
BY
}

\author{
A. H. M. SIDDONS \\ From St. George's Hospital, London, S.W.1
}

Since it is usually accepted that the more anaplastic bronchial carcinomas have a worse outlook, it might be thought that the type of cell found in a positive biopsy from bronchoscopy would give a clear lead as to prognosis. Indeed, Nicholson, Fox, and Bryce (1957) stated that the prognosis was best for squamous-celled growths and almost hopeless for spheroidal-celled, oatcelled, and anaplastic tumours. However, figures of five years' survival after resection published in this country and in the U.S.A. do not entirely support this view (Table I). Some authors have excluded those patients who did not long survive operation, and one paper reported only lobectomy as opposed to pneumonectomy. These variations should not invalidate comparison of the groups.

There is general agreement that excluding bronchial adenomas the cases fall into three broad groups: (1) squamous (epidermoid); (2) anaplastic (undifferentiated, including oat-celled); and (3) adenocarcinoma, which usually includes the very rare alveolar-celled type. Some authors (Kirklin, McDonald, Clagett, Moersch, and Gage, 1955) have pointed out that the anaplastic group can be divided into small- and large-celled types and that the former have a particularly bad prognosis. Table I shows that the outlook for the anaplastic group is indeed a little worse than that for the squamous type, but the difference is not great and

* Paper given to the meeting of the Thoracic Society in conjunction with the Société Française de Pathologie Respiratoire in Paris, 1962. a $20 \%$ expectation of survival for five years does not compare unfavourably with that for carcinoma in many other organs. Since the literature does not give a clear indication of whether cell type should influence the selection of patients for surgery, I thought that an analysis of and reflection on my own results might throw some light on this problem.

Up to February, 1957, I had done 250 resections for carcinoma of the bronchus: a few of the operations were done by my first assistant under my direct supervision, but I alone was responsible for the selection of patients. All patients were followed up, and their fate at the fifth anniversary of the operation is known for all but one: he was alive and well one year after operation, but has been presumed to have died before the fifth anniversary. The patients selected were those in whom it was thought that one of the standard operations could remove the whole growth, whose general health was good enough to withstand the operation, and in whom a simple clinical assessment suggested that pulmonary function was adequate. In selection for operation no consideration was given to the cell type, which was found at biopsy in 79 cases.

The resected specimens were examined by a number of different pathologists, and from their reports it was possible to place each case into one of the three groups given above. On the few occasions when the report left doubt as to how

TABle I

PATIENTS SURVIVING FIVE YEARS AFTER RESECTION FOR CARCINOMA OF THE BRONCHUS

\begin{tabular}{|c|c|c|c|c|c|c|c|c|c|}
\hline \multirow{3}{*}{ Author } & \multicolumn{3}{|c|}{ Squamous } & \multicolumn{3}{|c|}{ Anaplastic } & \multicolumn{3}{|c|}{ Adenocarcinoma } \\
\hline & \multirow{2}{*}{$\begin{array}{c}\text { Total } \\
\text { No. } \\
\text { Resected }\end{array}$} & \multicolumn{2}{|c|}{ Alive after Five Years } & \multirow{2}{*}{$\begin{array}{c}\text { Total } \\
\text { No. } \\
\text { Resected }\end{array}$} & \multicolumn{2}{|c|}{ Alive after Five Years } & \multirow{2}{*}{$\begin{array}{c}\text { Total } \\
\text { No. } \\
\text { Resected }\end{array}$} & \multicolumn{2}{|c|}{ Alive after Five Years } \\
\hline & & No. & $\%$ & & No. & $\%$ & & No. & $\%$ \\
\hline $\begin{array}{l}\text { Kirklin et al. (1955) } \\
\text { Bignall and Moon (1955) } \\
\text { Gifford and Waddington (1957) } \\
\text { Gibbon et al. (1957) } \\
\text { Paulson (1957) } \\
\text { Collins (1958) } \\
\text { Belcher (1959) } \\
\text { Christiansen and Smith (1962) }\end{array}$ & $\begin{array}{r}88 \\
275 \\
192 \\
105 \\
120 \\
71 \\
158 \\
47\end{array}$ & $\begin{array}{l}(30)^{*} \\
(99) \\
(73) \\
25 \\
(20) \\
16 \\
(51) \\
6\end{array}$ & $\begin{array}{l}(34) \\
36 \\
38 \\
(24) \\
17 \\
21 \\
32 \\
(13)\end{array}$ & $\begin{array}{r}71 \\
118 \\
120 \\
30 \\
20 \\
25 \\
42 \\
6\end{array}$ & $\begin{array}{c}(18) \\
(31) \\
(23) \\
4 \\
0 \\
1 \\
(16) \\
1\end{array}$ & $\begin{array}{c}25 \\
26 \\
19 \\
(13) \\
0 \\
4 \\
37\end{array}$ & $\begin{array}{r}25 \\
60 \\
35 \\
8 \\
24 \\
11 \\
46 \\
8\end{array}$ & $\begin{array}{c}(13) \\
(25) \\
0 \\
1 \\
(5) \\
2 \\
(24) \\
1\end{array}$ & $\begin{array}{r}54 \\
41 \\
0 \\
22 \\
53\end{array}$ \\
\hline $\begin{array}{ll}\text { Totals } \\
\end{array}$ & 1,056 & 320 & 30 & 432 & 94 & 22 & 217 & 71 & 33 \\
\hline
\end{tabular}

* The figures in parenthesis have been calculated from those published; some of the papers quoted exclude post-operative deaths; Belcher's report was on lobectomy only. 
to classify a given case, the pathologist was asked to allot it to one of the three groups.

An analysis of the five-year survival rate for the three histological types showed that the anaplastic group had a better result than the squamous-celled group. As this was contrary to the findings of most others, the group classification was done a second time by my colleague, Professor $T$. Crawford, without knowledge of the previous classifications or clinical results. In 221 of the 250 cases microscopic slides were still available and further analysis of this series will be confined to these 221 cases. The definition of the groups was identical in the two classifications with the exception that in the second, done by Professor Crawford, cases showing areas of both differentiated and undifferentiated cells were classified under the differentiated groups, i.e., squamous or adenocarcinoma. The change was made to keep in line with other speakers at the Paris meeting of the Thoracic Society in July, 1962, when these figures were first presented. Because of this change, it might be expected that some cases would be moved during re-classification from the undifferentiated to the other two groups. This in fact did occur in 31 of the 221 cases, but Table II shows that in 28 other cases the classification was also changed, and in 20 this change was from the differentiated to the undifferentiated group.

\section{TABLE II}

RECLASSIFICATION BY A SECOND PATHOLOGIST OF 221 CASES OF CARCINOMA OF THE BRONCHUS

Anaplastic to squamous
Anaplastic to adenocarcinoma
Squamous to anaplastic
Adenocarcinoma to anaplastic
Squamous to adenocarcinoma
Adenocarcinoma to squamous

$$
\frac{3}{59}
$$

The five-year survival rate in each group appeared to differ considerably in two classifications (Table III). If those cases where the group was changed are discarded, the figures are as in Table IV.

It has been suggested that the oat-celled type might usefully be separated from the undifferentiated group. Professor Crawford considered 28 cases to be of this group; of these, six survived five years. There were six cases of the small-celled type (see Kirklin et al., 1955) ; two of these lived five years.

Before any conclusions can be drawn from this investigation it must be emphasized that the histological classification was based on the study of resected specimens and not on the biopsies. In only 79 of the 221 cases was a positive biopsy available for microscopic assessment. Taylor
TABLE III

FIVE-YEAR SURVIVAL RATE IN TWO CLASSIFICATIONS

\begin{tabular}{lccc} 
& & \multicolumn{2}{c}{ Alive after Five Years } \\
\cline { 3 - 4 } Type & Total & No. & $\%$ \\
\hline Anaplas' ic & $69(58) *$ & $26(18)$ & $37.6(31 \cdot 2)$ \\
Squamous & $122(131)$ & $39(47)$ & $32 \cdot 2(35 \cdot 8)$ \\
Adenocarcinoma & $30(32)$ & $13(13)$ & $43 \cdot 3(40 \cdot 6)$ \\
Totals & 221 & 78 & $35 \cdot 2$ \\
* Second classification figures in parentheses.
\end{tabular}

TABLE IV

FIVE-YEAR SURVIVAL RATE FOR CASES REMAINING IN SAME GROUP ON RECLASSIFICATION

\begin{tabular}{lccc}
\multirow{2}{*}{ Type } & Total & \multicolumn{2}{c}{ Alive at Five Years } \\
\cline { 4 - 5 } & No. & No. & $\%$ \\
\hline Squamous & 100 & 39 & 39 \\
Adenocarcinoma & 24 & 10 & 42 \\
Anaplastic & 38 & 13 & 34
\end{tabular}

(1962) stated that in his series the cell type had been classified correctly in only $90 \%$ of the biopsies, since more cases were classified as undifferentiated when the whole specimen was available. In my series, of the 162 cases similarly classified on the two occasions, 54 had had positive biopsies and in four of these the biopsy was interpreted differently from the resected specimen.

\section{Conclusion}

Figures for the five-year survival of patients with bronchial carcinoma of various cell types are dependent on the pathologist's classification. Although three general cell types can be defined (squamous, anaplastic, and adenocarcinoma) it is not possible to allot with accuracy every individual specimen to one of these categories. In this series of 221 cases a second pathologist classed one quarter of the cases differently.

Even if the more doubtful cases which are classed differently by different pathologists are excluded, the chance of a five-year survival after operation is not greatly different in the three groups, suggesting that cell type should not influence the surgeon in selecting patients for operation.

\section{REFERENCES}

Belcher, J. R. (1959) Lancet, 2, 639.

Bignall, J. R., and Moon. A. J. (1955). Thorax, 10, 183.

Christiansen, K. H., and Smith, D. E. (1962). J. thorac. cardiovasc. Surg., 43, 267.

Collins, N. P. (1958). Arch. Surg., 77, 925.

Gibbon, J. H., Jr., Templeton, J. Y., and Nealon, T. F. (1957). Ann. Surg., 145, 637 .

Gifford, J.' H., and Waddington, J. K. B. (1957). Brit. med. J., 1, 723. Kirklin, J. W. McDonald, J. R., Clagett, O. T., Moersch, H. J., and Gage, R. P. (1955). Surg. Gvnec. Obstet., 100, 429.

Nicholson, W. F., Fox, M., and Bryce, A. Graham (1957). Lancet, 1, 296.

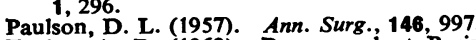

Taylor, A. B. (1962). Paper read at Paris Meeting of Thoracic Society, July, 1962. 